\title{
"Schizophonophilia": An Audio-Interplay Between Wayde Compton and Paul Watkins
}

\author{
Original Interview: Access here.
}

Remix 1 (Schizophonophilia Mix): Access here.

Remix 2 (British Columbian Blues, Bass Mix): $\underline{\text { Access here. }}$

Remix 3 (British Columbian Blues, Hendrix Mix): Access here.

Wayde Compton is a Black Canadian writer/poet, DJ, and historian, born and raised in Vancouver, British Columbia. Compton has published two books of poetry: 49th Parallel Psalm and Performance Bond. He has also edited an anthology, Bluesprint: Black British Columbian Literature and Orature, and more recently, a collection of essays entitled After Canaan: Essays on Race, Writing, and Region. His latest work is his debut story collection, The Outer Harbour: Stories. He co-founded Commodore Books, the first black-oriented press in Western Canada, with David Chariandy and Karina Vernon in 2006. He's also been involved with the recovery of Hogan's Alley in Vancouver, a historically black neighbourhood that was removed in the 1960s for a highway. Compton co-founded the Hogan's Alley Memorial Project in 2002, a grassroots organization that archives the history of Vancouver's black community. In addition to his published writing, Compton is known for his engaging and improvisational approach to reading his work, often performing turntable-based sound poetry with his collaborative partner, DJ Jason de Couto. Compton is currently the director of The Writer's Studio, a creative writing program in Continuing Studies at Simon Fraser University.

In his essay, "Turntable Poetry, Mixed-Race, and Schizophonophilia," Compton describes "schizophonophilia" as the "love of audio interplay, the pleasure of critical disruptions to natural audition, the counter-hegemonic affirmation that can be achieved through acoustic intervention" (199). The notion of acoustic intervention is a reminder that democracy can be embodied in sound and often be most effective when most discordantly free. Such sonic dialogism is also the embodied reality of a history and culture in flux. In Bluesprint, Compton purports that British Columbia's "black history has been one of continued exodus, immigration, settlement, exploration, miscegenation, communitarianism, integration, segregation, agitation, uprooting and re-rooting and re-routing" (20).

Taking up the aforementioned themes, Paul Watkins sits down in Wayde Compton's office in Vancouver for a personal and engaging interview. They discuss, among other topics, Black British Columbian history, the historic black community of Hogan's Alley, identity and race, improvising Blackness, Compton's literary influences, the importance of tradition, formal and stylistic innovations, Kamau Brathwaite's notion of tidalectics (a cyclical interpretation of history), ${ }^{1}$ multiculturalism, the role of the DJ as archivist, and the music and culture of hip-hop and jazz.

The interview is available in a variety of audio formats, including its original unedited version and three sonic remixes, allowing the interview to embody the practice of "schizophonophilia" rather than only theorizing it. The first remix ("Schizophonophilia Mix") takes various sound clips from the interview and collages them with assorted mixed productions from DJ Techné (turntable sound artist Paul Watkins). ${ }^{2}$ At the end of the interview, Wayde Compton reads a short prose piece, "British Columbian Blues" (now officially titled "The Instrument"), that is remixed in two versions: one featuring David Lee improvising (in a single take) on bass and the other combining Lee's bass with various Jimi Hendrix samples compiled by DJ Techné. ${ }^{3}$ By intentionally not providing a transcript, Compton and Watkins intend for the listener to focus on the sonic collisions and nuances within the interview. Given that the cypher is the unifying theme of this issue, leaving the interview in its oral and predominantly improvisatory format emphasizes how ideas move and coalesce, just as a cypher does, in a complex matrix of sharing.

This interview first appeared on the Improvisation, Community, and Social Practice Project's website as a featured Oral History. It is republished here by permission of Wayde Compton and Paul Watkins.

\section{Notes}

${ }^{1}$ Discussing tidalectics in an interview with Nathaniel Mackey, Brathwaite describes how history can be seen as cyclical: "In other words, instead of the notion of one-two-three Hegelian, I am now more interested in the movement of backwards and forwards as a kind of cyclic, I suppose, motion, rather than linear" (44). 
${ }^{2}$ While most of the drum programming was created live (I also beatbox, scratch, and play guitar, singing bowl, and other instruments throughout) without the use of recognizable samples, there are numerous samples in "Schizophonophilia Mix" that are taken from a variety of records, and those that I can recall include Timothy Leary: Psychedelic Experience; Glenn Gould: Glenn Gould In Conversation with John McClure; Ella Fitzgerald and Louis Armstrong: "Moonlight in Vermont"; John Coltrane: "Om, Part 1"; Miles Davis: Sketches of Spain; Louis Armstrong: "(What Did I Do To Be So) Black and Blue"; Thelonious Monk: "Epistrophy"; Sun Ra: Sleeping Beauty (various samples); Charlie Parker: "Bird of Paradise"; build an ark: "sunshine"; and Charles Mingus: "Pithecanthropus Erectus."

${ }^{3}$ Samples include "Voodoo Child”; “Are you Experienced?”; “Little Miss Lover”; “Fire”; and "Purple Haze.”

\section{Works Cited}

Brathwaite, Edward Kamau. "An Interview with Kamau Brathwaite." Interview by Nathaniel Mackey. Hambone 9 (1991): 42-59. Print.

Compton, Wayde. Bluesprint: Black British Columbian Literature and Orature. Vancouver: Arsenal Pulp, 2001. Print.

---. "Turntable Poetry, Mixed-Race, and Schizophonophilia." After Canaan: Essays on Race, Writing, and Region. Vancouver: Arsenal Pulp, 2010. 183-201. Print. 